Корогод Н.П., Фонарьова Т.А.

До питання структури інтелектуального капіталу та оцінки людського капіталу, як його складової, при визначенні ринкової вартості підприсмства металургійної галузі

\title{
Korogod N., Fonarova T. \\ To the question of the structure of intellectual capital and the assessment of human capital as its component in determining the market value of the metallurgical industry enterprises
}

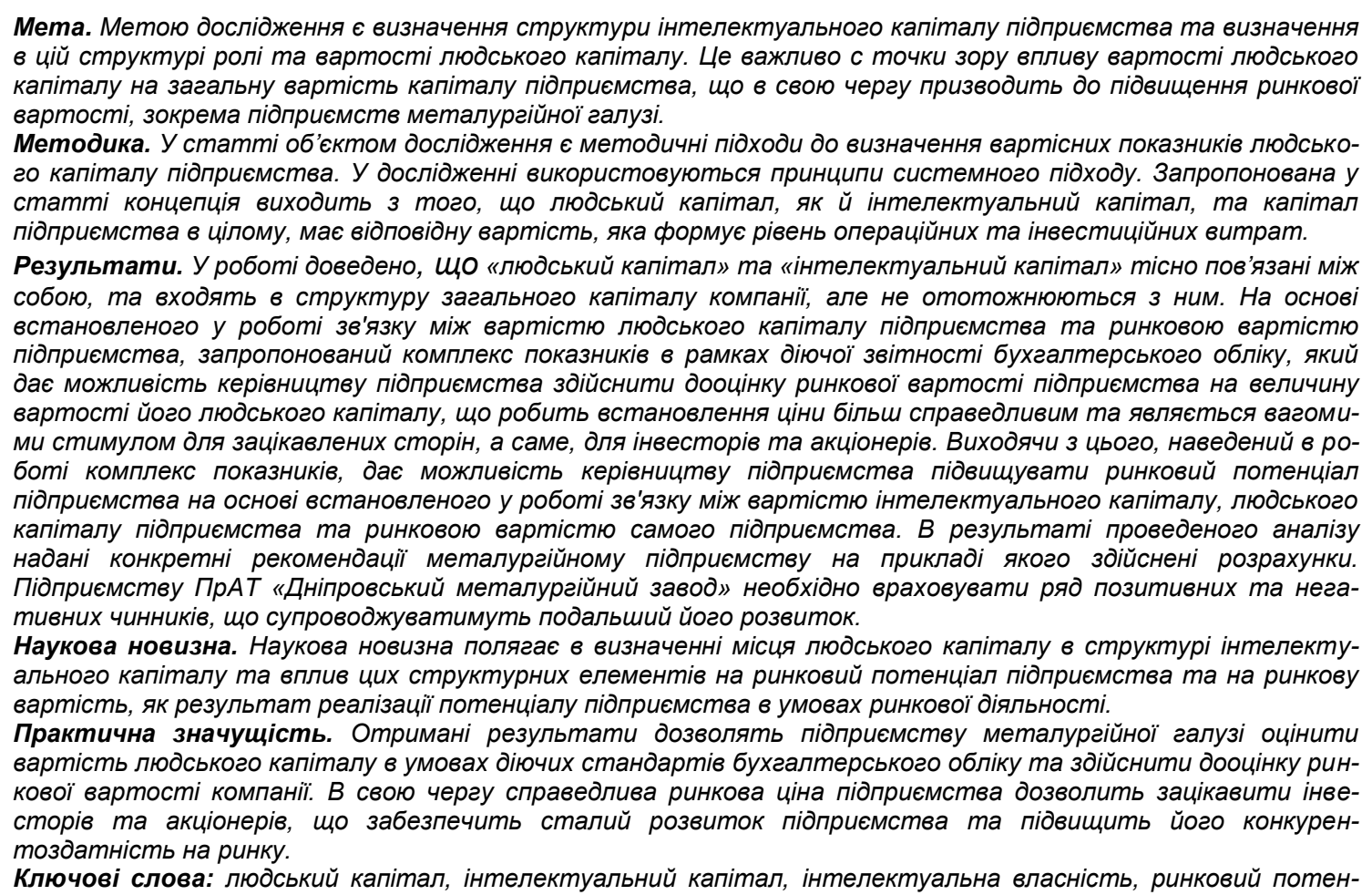
ціал, вартість, підприємство.

Purpose. The purpose of the study is to determine the structure of intellectual capital of an enterprise and to determine in this structure the role and value of human capital. This is important in terms of the impact of the value of human capital on the total cost of capital of the enterprise, which in turn leads to an increase in market value, in particular, metallurgical enterprises.

Methodology. In the article the object of research is methodical approaches to the definition of cost indicators of human capital of the enterprise. The study uses the principles of a systematic approach. The concept proposed in the article is based on the assumption that human capital, as well as intellectual capital, and capital of the enterprise as a whole, has the corresponding value, which forms the level of operating and investment costs.

Findings. It is proved in the paper that "human capital" and "intellectual capital" are closely interconnected, and are part of the overall capital structure of the company, but are not identified with it. On the basis of the established relationship between the value of human capital of the enterprise and the market value of the enterprise, a set of indicators is provided within the framework of the current accounting reporting, which enables the management of the company to carry out an additional assessment of the market value of the enterprise by the value of its human capital, which makes the price setting more fair and is a powerful incentive for stakeholders, namely investors and shareholders. Proceeding from this, the set of indicators presented in the work enables the management of the enterprise to increase the market potential of the enterprise on the basis of the relationship established between the work value of intellectual capital, the human capital of the enterprise and the market value of the enterprise itself. As a result of the analysis, concrete recommendations were given to the metallurgical enterprise, for which the calculations were made. The enterprise of Dniprovsky Metallurgical Plant should consider a number of positive and negative factors that will accompany its further development.

Originality. Scientific novelty is to determine the place of human capital in the structure of intellectual capital and the influence of these structural elements on the market potential of the enterprise and on the market value, as a result of realization of the potential of the enterprise in the conditions of market activity.

Practical value. The results will allow the metallurgical industry to estimate the value of human capital in the current accounting standards and to make an overvaluation of the market value of the company. In turn, the fair market price of

Корогод Наталія Петрівна - к.пед.н, доц., НМетАУ Фонарьова Тетяна Анатоліївна - НМетАУ
Korogod Natalia - c.p.s., assistant professor NmetAU

Fonarova Tetiana - NmetAU 
the company will allow investors and shareholders to be interested in ensuring sustainable development of the enterprise and increasing its competitiveness in the market.

Keywords. Human capital, intellectual capital, intellectual property, market potential, cost, enterprise.

Вступ. Сучасний етап розвитку економіки характеризується посиленим впливом знань та інформації на суб'єктів господарювання всіх рівнів. Специффічною ознакою економіки знань є поява все більш складних нематеріальних фрорм капіталу, які володіють більшим потенціалом. Ці зміни неодмінно сприяють включенню України в загальний рух до економіки знань. Отже, на перший план виходять інтелектуальні ресурси. Але не зважаючи на те, що існує велика кількість наукових підходів до визначення таких ресурсів, актуальними є питання формування структурних елементів таких понять як інтелектуальний потенціал, інтелектуальний капітал, людський капітал. Важливим є визначення взаємозв'язку між ними, та обліку й оцінки в структурі загального капіталу підприємства. Ці аспекти мають особливе значення для металургійної галузі. Саме металургійні підприємства потребують новітніх підходів до реконструкції, раціоналізації праці, оновлення технологій, втілення інноваційних проектів і програм, інвестицій в персонал з метою забезпечення конкурентних переваг на міжнародному ринку i, як наслідок, підвищення ринкової вартості підприємства.

Аналіз літературних даних та постановка

\begin{tabular}{|c|c|}
\hline Автор класифрікації & Перелік структурних елементів \\
\hline Л. Едвінсон & $\begin{array}{l}\text { людський капітал; } \\
\text { структурний капітал }\end{array}$ \\
\hline К. Свейбі & $\begin{array}{l}\text { 3овнішня структура; } \\
\text { внутрішня структура; } \\
\text { індивідуальна компетенція }\end{array}$ \\
\hline Е. Брукінг & $\begin{array}{l}\text { ринкові активи; } \\
\text { людські активи; } \\
\text { інфраструктурі активи; } \\
\text { ринкова вартість }\end{array}$ \\
\hline Т. Стюарт & $\begin{array}{l}\text { людський капітал; } \\
\text { структурний капітал; } \\
\text { клієнтський капітал }\end{array}$ \\
\hline Р. Каплан, Д. Нортоң & $\begin{array}{l}\text { клієнти; } \\
\text { внутрішня структура підприємства; } \\
\text { iнноваційні та навчальні процеси; } \\
\text { фрінанси }\end{array}$ \\
\hline А. Чухно & $\begin{array}{l}\text { людський капітал; } \\
\text { технологічний капітал }\end{array}$ \\
\hline О. Кедюхов & $\begin{array}{l}\text { персоніфікований капітал; } \\
\text { інфраструктурний капітал; } \\
\text { клієнтський капітал; } \\
\text { марочний капітал; } \\
\text { фрормалізована інтелектуальна влас- } \\
\text { ність }\end{array}$ \\
\hline П. Цибульов & $\begin{array}{l}\text { людський капітал; } \\
\text { структурний капітал; } \\
\text { права на об'єкти і інтелектуальноі } \\
\text { власності }\end{array}$ \\
\hline
\end{tabular}

проблеми.

На сьогодні немає єдиного загальновизнаного підходу до визначення структури інтелектуального капіталу (ІК) підприємства, різні дослідники мають власні точки зору щодо цього питання ( див. табл. 1)[1]

Як видно 3 таблиці 1, людський капітал (ЛК), є невід'ємною частиною ІК. Зважаючи на певну схожість понять «інтелектуальний капітал» і «людський капітал», між ними є суттєва різниця. Адже людський капітал - це скоріше вартісна оцінка роботи сукупності працюючих на відповідному фаховому рівні (вищому рівні кваліфікації), які розглядають як потенційні носії ідеї, спрямованих на процес розробки інтелектуального продукту корисного для суспільства. В цьому випадку ефективність живої праці буде визначатися кількістю створеного інтелектуального продукту на одиницю робочого часу. Цей показник може характеризувати людський потенціал, якщо визначати потенційні можливості створювати інтелектуальний продукт за відповідний термін [2].

У зв'язку з активним залученням інтелектуальної власності у всі сфери діяльності, сьогодні актуальним $€$ визначення взаємозв'язку з інтелектуальним капіталом та впливу на формування ринкової вартості підприємства.

Інтелектуальний капітал - це інтелектуальний потенціал, що активно використовується суб'єктами господарювання у процесі економічного розвитку з метою отримання доходу, і являє собою сукупність знань працівників підприємства, що забезпечує його конкурентоспроможність. В свою чергу, інтелектуальний потенціал (ІП) - це можливості, створені інтелектуальними ресурсами. Іншими словами, інтелектуальний капітал розглядається як реалізований інтелектуальний потенціал. Інтелектуальний капітал розраховується як різниця між ринковою вартістю і балансовою вартістю підприємства.[3]

Цілком очевидно, що інтелектуальна власність впливає на формування й вартісних показників різних видів потенціалу підприємства. Компоненти інтелектуального потенціалу (ІП) та інтелектуального капіталу за ознаками представлені в табл. 2. [2].

За ознакою фрормування інтелектуальний капітал поділяється на створений самим суб'єктом господарювання i придбаний у інших суб'єктів господарювання. Як 
провідний чинник та основа інтелектуальної економіки, інтелектуальний капітал має такі специфрічні ознаки:

- не є матеріальним у традиційному розумінні, хоча форми, яких набувають інтелектуальні активи, можуть бути матеріальними;

- перебуває одночасно у формах запасу і продукту, його споживання $є$ водночас його примноженням;

- зберігається та нагромаджується у специфічних, нетрадиційних формах;

- $€$ основним компонентом визначення ринкової вартості сучасних підприємств.
При цьому дослідники розрізняють:

- сукупний інтелектуальний капітал - сукупність знань, досвіду, зв'язків, інформації, що накопичені і використовуються на рівні суспільства в цілому;

- інтелектуальний капітал фрірми - сукупність активів окремої фрірми, заснованих на інтелектуальних здібностях її співробітників, що реалізуються в процесі інноваційної діяльності;

- інтелектуальний капітал індивіда - сукупність знань, досвіду, професійних навичок та інтелектуальних здібностей особистості [4].

Таблиця 2 - Компоненти ІП та інтелектуального капіталу за ознаками [2]

\begin{tabular}{|c|c|c|c|c|}
\hline \multirow[b]{2}{*}{ Ознаки } & \multicolumn{2}{|c|}{ Інтелектуальний потенціал } & \multicolumn{2}{|l|}{ Інтелектуальний капітал } \\
\hline & $\begin{array}{l}\text { Людські ресур- } \\
\text { си (інтелектуа- } \\
\text { льна сила) }\end{array}$ & $\begin{array}{l}\text { Інтелектуальні } \\
\text { ресурси } \\
\text { лектуальний продукт) }\end{array}$ & Людський капітал & $\begin{array}{l}\text { Інтелектуальні } \\
\text { активи (немате- } \\
\text { ріальні активи) }\end{array}$ \\
\hline $\begin{array}{l}\text { Можливості } \\
\text { передачі } \\
\text { знання }\end{array}$ & $\begin{array}{l}\text { Кількість пра- } \\
\text { цюючих які ро- } \\
\text { зробляють або } \\
\text { володіють } \\
\text { знаннями, що } \\
\text { можна іденти- } \\
\text { фікувати }\end{array}$ & $\begin{array}{l}\text { Знання, які описані } \\
\text { на матеріальних но- } \\
\text { сіях і які можна захи- } \\
\text { стити правовим } \\
\text { механізмом і } \\
\text { передати (комерціа- } \\
\text { лізувати) }\end{array}$ & $\begin{array}{l}\text { Вартісна оцінка робочої } \\
\text { сили, інтелектуальних } \\
\text { зусиль одного чи сукуп- } \\
\text { ності } \\
\text { (колективний } \\
\text { інтелект) працівників, які } \\
\text { в знаходяться процесі } \\
\text { розробки інтелек- } \\
\text { туального продукту } \\
\text { або намагаються пере- } \\
\text { дати свої знання }\end{array}$ & $\begin{array}{l}\text { Вартість об'єктів } \\
\text { інтелектуальної } \\
\text { власності за } \\
\text { результатам } \\
\text { введення до гос- } \\
\text { подарського обі- } \\
\text { гу }\end{array}$ \\
\hline Приклади & $\begin{array}{l}\text { Досвід } \\
\text { Професійні } \\
\text { знання } \\
\text { Групові та } \\
\text { індивідуальні } \\
\text { навички } \\
\text { Творчість }\end{array}$ & $\begin{array}{l}\text { Плани, програми } \\
\text { Коди, правила, фрор- } \\
\text { мули } \\
\text { Комп'ютерні } \\
\text { програми } \\
\text { Технології, винаходи } \\
\text { Процеси } \\
\text { Публікації }\end{array}$ & $\begin{array}{l}\text { Вартісна оцінка інтелек- } \\
\text { туальних зусиль }\end{array}$ & $\begin{array}{l}\text { Вартісна оцінка } \\
\text { конкретного ви- } \\
\text { ду } \\
\text { інтелектуального } \\
\text { продукту (нема- } \\
\text { теріального ак- } \\
\text { тиву) }\end{array}$ \\
\hline Джерело & $\begin{array}{l}\text { Люди, практи- } \\
\text { ка та проце- } \\
\text { дури організа- } \\
\text { ції }\end{array}$ & $\begin{array}{l}\text { Матеріальні носії ін- } \\
\text { формації, які можна } \\
\text { ідентифікувати }\end{array}$ & $\begin{array}{l}\text { Вартісна оцінка джерела } \\
\text { інфрормації на матеріа- } \\
\text { льному носії }\end{array}$ & $\begin{array}{l}\text { Вартість іннова- } \\
\text { ції (інноваційного } \\
\text { продукту, } \\
\text { інноваційної } \\
\text { продукції) }\end{array}$ \\
\hline $\begin{array}{l}\text { Методи } \\
\text { правової } \\
\text { охорони }\end{array}$ & $\begin{array}{l}\text { Комплексна } \\
\text { угода між пра- } \\
\text { цівником і ро- } \\
\text { ботодавцем }\end{array}$ & $\begin{array}{l}\text { Патентне право } \\
\text { Авторське право } \\
\text { Комерційні секрети }\end{array}$ & $\begin{array}{l}\text { Вартість угоди, автор- } \\
\text { ської винагороди }\end{array}$ & $\begin{array}{l}\text { Вартість угоди, } \\
\text { авторської вина- } \\
\text { городи }\end{array}$ \\
\hline
\end{tabular}

Слід зазначити, що визначення й розрахунки кількісних і якісних показників інтелектуального потенціалу та людського капіталу передбачає наявність спеціалізованих економічних знань, якими працівники та менеджери вітчизняних підприємств не володіють в повній мірі. Так, наприклад, в системі бухгалтерського обліку величину інтелектуального потенціалу підприємства можна розрахувати наступним чином:

IП $=K_{\text {ЧК }} *\left(\mathrm{~B}_{\mathrm{IK}}+\mathrm{B}_{\mathrm{MA}}\right)$,

де $\kappa_{\text {чк }}$ - коефріцієнт якості людського капіталу;

$\mathrm{B}_{\text {IК }}$ - ринкова вартість інтелектуальної власності підприємства;
$\mathrm{B}_{\mathrm{MA}}$ - ринкова вартість маркетингових активів підприємства.

Коефіцієнт якості людського капіталу (Кчк) визначається за фрормулою:

$\mathrm{K}_{\mathrm{UK}}=\frac{\left[\mathrm{B}_{\mathrm{A}}-\left(\mathrm{B}_{\mathrm{MA}}+\mathrm{B}_{\mathrm{HA}}\right)\right]}{\mathrm{B}_{\mathrm{IK}}+\mathrm{B}_{\mathrm{MA}}}$,

де $\mathrm{B}_{\mathrm{A}}$ - оцінка вартості всіх акцій підприємства;

$\mathrm{B}_{\mathrm{MA}}$ - ринкова вартість матеріальних активів підприємства;

$\mathrm{B}_{\mathrm{HA}}$ - ринкова вартість нематеріальних активів підприємства;

$\mathrm{B}_{\mathrm{HA}}$ - ринкова вартість тієї частки нематеріальних активів, яку складають майнові права (право 
на використання землею, ресурсами і інші подібні права.

Важливо підкреслити, що чисельник формули представляє собою ринкову оцінку вартості інтелектуального потенціалу, тому що з ринкової вартості всіх активів підприємства віднімається вартість всієї власності, окрім нематеріальних активів, що є об'єктами права інтелектуальної власності. Слід додати, що коефіцієнт якості людського капіталу може приймати значення більші та менші за одиницю, при чому якщо він більше одиниці, то тоді виникає необхідність в нарощуванні людського капіталу [5].

Водночас, такий підхід до визначення співвідношення між інтелектуальним капіталом підприємства та його складовими елементами призводить до певних труднощів. Зокрема, труднощі виникають тому що, різні складові інтелектуального капіталу можуть перетинатися, та, як наслідок, подвійно враховуватися, перетікати з одної форми в іншу, та підсилювати один одного в рамках синергетичного ефекту. Це утруднює та інколи унеможливлює облік як інтелектуального капіталу так й його складових в рамках загальноприйнятої системи бухгалтерського обліку. Отже, постає проблема пошуку шляхів обліку та оцінки як інтелектуального капіталу, так і людського капіталу підприємств. Необхідно розробити методичні підходи та використовувати комплекс вартісних показників, які б враховували та коректувалися під потреби та особливості кожного конкретного підприємства, зокрема металургійної галузі виробництва.

Мета і завдання дослідженя. Метою дослідження $є$ систематизація особливостей прояву й місця людського капіталу в структурі інтелектуального капіталу підприємства, визначення рівнів де він функціонує, здійснення оцінки його вартості для підприємства металургійної галузі.

Матеріали та методи дослідження. Дослідження побудовано на положеннях і принципах системного підходу. Саме на цьому підході будується сучасна «теорія людського капіталу», в рамках якої людська складова економічних систем різного масштабу розглядається в термінах вартості та ціни і розрізняється по визначенню за трьома рівнями [6]:

- на особистісному рівні людським капіталом називаються знання і навички, які людина отримала шляхом освіти, професійної підготовки, практичного досвіду (використовуючи при цьому свої природні здібності) і завдяки яким вона може надавати цінні виробничі послуги іншим людям. На цьому рівні людський капітал можна порівняти 3 іншими видами особистої власності (майно, гроші, цінні папери), яка приносить доходи, і ми називаємо його особистим, або приватним людським капіталом;

- на мікроекономічному рівні людський капітал являє собою сукупну кваліфікацію та професійні здібності всіх працівників підприємства, а також досягнення підприємства в справі ефективної організації праці і розвитку персоналу. На цьому рівні людський капітал входить в інтелектуальний капітал всього підприємства, та асоціюється 3 виробничим та комерційним капіталом підприємства, так прибуток виходить від ефективного використання всіх видів капіталу;

- на макроекономічному рівні людський капітал включає накопичені вкладення в такі галузі діяльності, як освіта, професійна підготовка і перепідготовка, служба профорієнтації та працевлаштування, оздоровлення тощо, $є$ суттєвою частиною національного багатства країни, і ми називаємо його національним людським капіталом. Цей рівень включає всю суму людського капіталу всіх підприємств і всіх громадян (без повторного рахунку), як і національне багатство включає багатство всіх громадян і всіх юридичних осіб.

Отже, незалежно від того, який рівень людського капіталу досліджується, базовим структурним елементом завжди залишається індивідуальний людський капітал (ІЛК), який має свою ціну і ефективність використання в залежності від того, до якої соціально-економічної групи він відноситься.

Спираючись на логіку оцінки вартості національного людського капіталу [7] визначено три основних показника вартісної оцінки людського капіталу (формули 3, 4, 5) [8]:

$$
\text { ВІЛК }=\text { ВВП }_{1} \times \mathrm{I}_{\mathrm{i} л к}^{\mathrm{e}} \times m
$$

де: $В І Л К$ - вартість індивідуального людського капіталу, грн.;

$B B \Pi_{1}$ - валовий внутрішній продукт на душу населення в України, грн.;

m - стаж роботи окремого працівника.

$\mathrm{I}_{\mathrm{i} к}^{\mathrm{e}}$ - індекс ефрективності індивідуального людського капіталу:

$$
\mathrm{I}_{\mathrm{i} л к}^{\mathrm{e}}=\frac{\text { валова додана вартість ВВП }}{\text { наявні доходи населення }}
$$

Середня ціна використання (надання кредиту) в національній економіці індивідуального людського капіталу виражену у відсотках до його вартості $\mathrm{T}_{\%}^{\mathrm{cp}}$

$$
\mathrm{T}_{\%}^{\mathrm{cp}}=\frac{\text { витрати на оплату праці найманих робітників }}{\text { випуск продукції }} \times 100 \%
$$

Отже, індивідуальний людський капітал розглядається як власність самого працівника, а ринкова ціна його праці та доход від вкладених в його розвиток підприємством коштів і є та ціна, яку сплачує підприємство за можливість використання (запозичення) індивідуального людського капіталу і згідно теорії відсотка [9] визначається як частка (процент) від основної суми капіталу. В сучасних умовах господарювання ситуація складається здебільшого так, що ціну використання (запозичення) індивідуального людського капіталу призначає підприємство, яке наймає працівника. Безумовно, висококваліфіковані працівники мають можливість впливати на розмір поточного або майбутнього капіталу (при обговоренні умов кон- 
тракту-найму), але все ж таки визначальне слово залишається за підприємством (вірніше його керівником або власником). Тому вартість індивідуального людського капіталу визначається в умовах конкретного підприємства.

\section{Результати дослідження.}

У зв'язку з активним залученням інтелектуальної власності у всі сфрери діяльності, сьогодні актуальним $€$ визначення місця та ролі ЛК у структурі загального потенціалу підприємства як зв'язуючого елементу людського, трудового, наукового, інноваційного потенціалу (рисунок 2).

Рівнем розкриття, реалізації того чи іншого потенціалу завжди виступає «результат». Й відповідно кількісна оцінка людського капіталу, здійснюється через фіксацію певних результатив- них параметрів. Саме результат реалізації людського потенціалу в умовах того чи іншого підприємства має виступати вартісною характеристикою його капіталу, а не сума витрат, спрямованих на удосконалення тієї чи іншої властивості людини. I цим результатом мають бути характеристики дохідності як на рівні підприємства в цілому, так і його окремого працівника.

Досліджуючи ринковий потенціал будь-якого підприємства, ми маємо на увазі певний комплекс характеристик та показників, через які це підприємство відображує свою діяльність як учасник ринку. Цей комплекс показників включає фінансові та не фрінансові показники, окремим блоком - показники витрат та ринкову вартість підприємства.

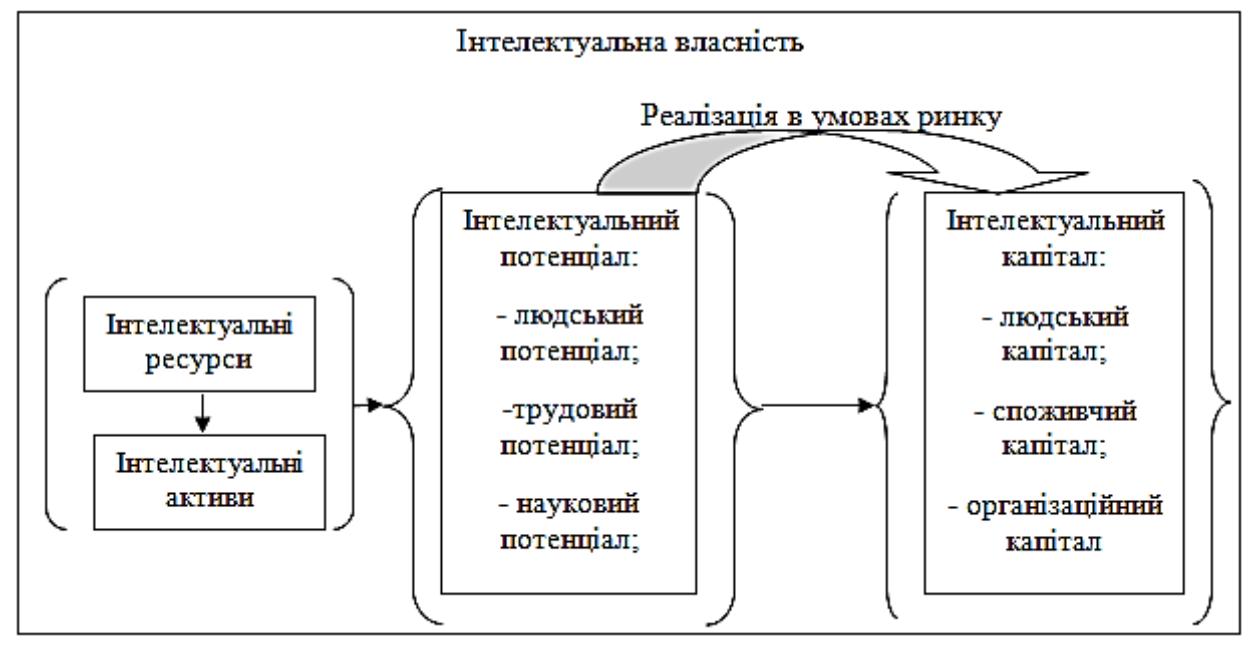

Рисунок 2 - Формування та взаємозв'язок інтелектуального потенціалу з інтелектуальним та людським капіталом підприємства

Але в умовах сучасної практики все частіше постають завдання оцінки ринкового потенціалу не тільки з боку власне підприємства, а й інших зацікавлених осіб - інвесторів, кредиторів, акціонерів та т.п. І тут вже має йти мова про більш конкретно відображені показники. І, частіше за все, таким показником виступає ринкова вартість підприємства. Ринкові чинники вартості знаходять своє відображення через відповідні фрінансові індикатори компаній, що фріксуються на основі даних бухгалтерського обліку - це відношення ринкової і бухгалтерської вартості компанії. При цьому формується певне відношення ринкової та бухгалтерської вартості показник РВ/БВ (див. табл. 2). [10]

Результати, наприклад, дослідження польських підприємств, показали, що для умов Польщі відношення ринкової вартості до бухгалтерської становить близько 2,84 [10]. Такий великий розрив це наслідок ефекту «Goodwill», не відображеного в активах, тобто недооцінювання нематеріальних активів підприємства, до яких, зокрема, належить і людський капітал (інтелектуальний капітал).

Таблиця 2 - Біржова капіталізація ma Goodwill провідних американських компаній [10]

\begin{tabular}{|l|l|l|l|l|}
\hline № & Компанія & $\begin{array}{l}\text { Капіталізація } \\
{[\text { Млн. \$] }}\end{array}$ & $\begin{array}{l}\text { Показник } \\
\text { РВ/БВ }\end{array}$ & Goodwill [млн. \$] \\
\hline 1 & General Electric & 286098 & 4,3 & 219564 \\
\hline 2 & Microsoft & 263990 & 4,7 & 207822 \\
\hline 3 & Exxon Mobil & 244932 & 3,3 & 170710 \\
\hline 4 & Pfizer & 244886 & 9,9 & 220150 \\
\hline
\end{tabular}

Наочним прикладом використання цих джерел з орієнтацією на їх «приховану» складову є вітчизняна практика «гри» у ринкову вартість підприємства. Підтвердженням цього фракту $€$ «ринкова історія» досліджуваного в роботі підприємства, сучасна назва якого - ПрАТ «Дніпровський металургійний завод». Завод, вже не вперше, опиняється перед вибором: або і далі працювати 
(зі збитками чи без них), або закрити підприємство, або просто продати. Відповідно для підприємства ставиться завдання визначення потенційної ринкової вартості підприємства, яка, як показує практика, не завжди відповідає його реальному фрінансовому положенню. На основі даних, отриманих на підприємстві, доведено вплив вартості людського капіталу на справедливу, тобто потенційно можливу його ринкову ціну (вартість). Для проведення розрахунків вартості людського капіталу підприємства (ВЛКП) було використано дані плановоекономічної звітності підприємства, і використовувалися ті параметри, що відображувалися в існуючий на підприємстві системі фрінансового та управлінського обліку. а саме: чисельність персоналу підприємства по категоріям, средньомісячна зарплата по структурним підрозділам заводу; використання робочого часу; скорочення трудовитрат за рахунок впровадження організаційно-технічних заходів.

Зважаючи, що визначальними чинниками при обліку вартості індивідуального людського капіталу (ВІЛК) є суми фрактично виплаченої заробітної плати (нарахованого зносу) та накопиченої вартості індивідуального людського капіталу, фрормулу 6 для розрахунку вартості людського капіталу підприємства (ВЛКП) у $t$-му році визначимо наступним чином:

$$
\text { ВЛКП }{ }^{t}=\left(1+\frac{T_{0}^{\mathrm{cp}, t}}{100}\right) \times \text { ВІЛ } \kappa_{\mathrm{H}}^{t} \times \mathrm{Ч}_{\Pi \Pi}^{t}-\mathrm{A}_{\mathrm{i} л \kappa}^{t}-\Pi_{\Pi \mathrm{H}}^{t}-\mathrm{E}_{\text {OТз }}^{t}
$$

де ВІЛК - накопичена віртість індивідуального людського капіталу 1-го працівника підприємства у t-му році, тис. грн.

$T_{\%}^{\mathrm{cp}, t}$ - середня ціна використання (надання кредиту) у національній економіці індивідуального людського капіталу кожного працівника підприємства у $t$-му році, \%;

$\mathrm{Ч}_{\Pi \text { }}^{t}$ - середньооблікова чисельність персоналу підприємства у $t$-му році;

$A_{\text {iлк }}^{t}$ - сума нарахованого зносу (фактично виплаченої заробітної плати) індивідуального людського капіталу у $t$-му році, тис. грн.;

$\Pi_{\Pi H}^{t}$ - сума втрат від факторів прямої та непрямої дії у $t$-му році, тис. грн.;

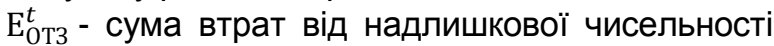
(за даними скорочення трудовитрат за рахунок впровадження організаційно-технічних заходів) у $t$ му році, тис. грн.

Суму нарахованого зносу ІЛК, тобто фрактично виплаченої заробітної плати $A_{\text {ілк }}^{t}$ у $t$-му році визначаємо за формулою:

$$
A_{\mathrm{i} л \kappa}^{t}=3_{\mathrm{cp}}^{t} \times 12 \times \mathrm{U}_{\Pi \Pi}^{t}
$$

де $3_{\mathrm{cp}}^{t}$ - середньомісячна зарплата на підприємстві у $t$-му році, тис. грн.;

12 - кількість місяців у році.

Суму втрат від факторів прямої та непрямої дії у $t$-му році П Пн визначаємо за фрормулою:
$\Pi_{\Pi \mathrm{H}}^{t}=3_{\mathrm{cp}}^{t} \times \frac{\Pi_{\mathrm{pu}}^{t}}{22,4^{\prime}}$

де $\Pi_{\mathrm{pq}}^{t}$ - втрати робочого часу на підприємстві у t-му році, людино-днів;

22,4 - середня норма кількості робочих днів у місяці.

Суму втрат від надлишкової чисельності (за даними скорочення трудовитрат за рахунок впровадження організаційно-технічних заходів) у $t$-му році $\mathrm{E}_{0 \mathrm{~T} 3}^{t}$ також визначаємо на основі даних таблиці 3.15 за фрормулою:

$$
\mathrm{E}_{\text {ОТ } 3}^{t}=\mathrm{Y}_{\mathrm{BOT} 3}^{t} \times 12 \times 3_{\mathrm{cp}}^{t},
$$

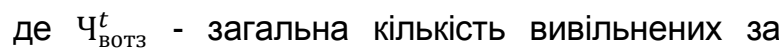
рахунок впровадження організаційно-технічних заходів у $t$-му році, осіб.

Розрахунки показали, що сумарна недооцінка ринкової вартості ПрАТ «Дніпровський металургійний завод» за рахунок накопиченої вартості людського капіталу склала 583 млн. грн. Окрім того, в результаті проведеного аналізу підприємству рекомендовано враховувати ряд позитивних (+) та негативних (-) чинників, що супроводжуватимуть подальший розвиток ПрАТ «Дніпровський металургійний завод», а саме:

+ зростання попиту на сталь в Україні;

+ активне використання об'єктів права інтелектуальної власності у якості нематеріальних активів підприємства;

+ збереження високих цін на метали на світових ринках;

+ можливий продаж підприємства профрільному стратегічному інвесторові;

+ розкриття власниками підприємства інформації про реальне фрінансове становище компанії;

+ реалізація програми з модернізації підприємства;

- непрозорість компанії для портфрельних інвесторів;

- різке падіння цін на сталь на світових ринках;

- зниження цін на акції інших українських металургійних компаній.

Обговорення результатів. Результати отримані авторами свідчать про те, що людський капітал впливає як на інтелектуальний капітал підприємства, так й на загальну вартість його капіталу, що підвищує його ринковий потенціал. В даний час область дослідження з вузького питання інвестицій в розвиток персоналу розширилася до надекономічних масштабів і займає увагу як власне економістів, так і фахівців з соціології, психології, менеджменту, фрілософії тощо. Відповідно, виникають певні відмінності в підходах до побудови визначень даної категорії. Автори пропонують свій погляд, згідно з яким людський капітал являється основою інтелектуального капіталу та впливає на вартісну оцінку капіталу підприємства в цілому. Відсутність чітких визначень і меж для різних класифікаційних груп, а також можливість пе- 
ретікання людського капіталу з однієї форми в іншу обумовлюють необхідність пошуку відповідних класифікаційних ознак і методів виділення його різновидів. В даному досліджені автори намагалися відповісти на питання - як вартість ЛК впливає на вартість підприємства в умовах ринку. В результаті здійснено систематизацію особливостей прояву і вивчення людського капіталу в залежності від того рівня де він функціонує і трансформується з однієї форми в іншу, визначено основні параметри, які відтворюють характеристики цього капіталу на різних рівнях в умовах конкретного металургійного підприємства.

\section{Висновки.}

1. Запропоновано розглядати людський капітал в межах логічного ланцюгу «ринковий потенціал підприємства - вартість підприємства - капітал інтелектуальний капітал -людський капітал». Кількісною характеристикою, що визначає однорідність даного ланцюга є параметр «вартість капіталу».

2. Визначено, що при оцінці людського капіталу слід відрізняти різні рівні його реалізації, а саме: національний людський капітал; людський капітал підприємства; індивідуальний людський капітал.

Оцінка показників людського капіталу на кожному з рівнів має свої певні особливості, але загальний їх масштаб та кількісні характеристики завдає рівень національного людського капіталу. Обґрунтовано, що індивідуальний людський капітал слід розглядати як власність самого працівника, при цьому ринкова ціна його праці та доход від вкладених в його розвиток підприємством коштів і $€$ та ціна, яку сплачує підприємство за можливість використання (запозичення) індивідуального людського капіталу і, згідно з теорією відсотка, визначається як частка (процент) від основної суми капіталу.
3. Визначено комплекс показників для оцінки вартості індивідуального людського капіталу в рамках діючої системи бухгалтерського обліку, який враховує вартісні особливості прояву людського капіталу на рівні підприємства в цілому, дозволяє змістити точку уваги менеджерів в управлінні людським капіталом з суми витрат на його реалізацію (що призводило до прийняття найпростіших рішень - їх скорочення), на суму втрачених та/або недоотриманих вигод підприємства.

4. В умовах дослідженого підприємства - ПрАТ «Дніпровський металургійний завод» здійснено апробацію запропонованого комплексу показників, які дозволяють керівництву підприємства встановити зв'язок між вартістю індивідуального людського капіталу, інтелектуального капіталу, людського капіталу підприємства та ринковою вартістю самого підприємства. Визначальними чинниками при обліку вартості індивідуального людського капіталу (ВІЛК), є суми фактично виплаченої заробітної плати (нарахованого зносу) та накопиченої вартості індивідуального людського капіталу. Окрім того, впливовими чинниками загальної вартості людського капіталу є втрати підприємства від фракторів прямої та непрямої дії, а також сума інвестицій у розвиток людського капіталу.

5. На основі даних, отриманих на підприємстві, авторами доведено вплив вартості людського капіталу на справедливу, тобто потенційно можливу його ринкову ціну (вартість). Розрахунки дозволили визначити сумарну недооцінку ринкової вартості ПрАТ «Дніпровський металургійний завод» за рахунок накопиченої вартості людського капіталу. Окрім того, в результаті проведеного аналізу підприємству рекомендовано враховувати ряд позитивних та негативних чинників, що супроводжуватимуть подальший розвиток ПрАТ «Дніпровський металургійний завод».

\section{Бібліографрічний опис.}

1. Чуприна О.О. Методологічні підходи до оцінювання інтелектуального капіталу / О.О. Чуприна, К.С. Чуприн // Вісник Національного університету «Юридична академія України імені Ярослава Мудрого» № 3 (14) 2013. С. 22-34.

2. Бутнік-Сіверський О.Б. Економіка інтелектуальної власності: конспект лекцій для студентів спеціальності 7.000002 «Інтелектуальна власність». - К.: Ін-т ін тел. власн. і права, 2003. - 296 с.

3. Базилевич В.Д. Інтелектуальна власність: Підручник. - Київ: Знання, 2006.-431с.

4. Морозов О. Система управління інтелектуальним капіталом підприємства як механізм захисту прав інтелектуальної власності (ч. 1) [Текст] / О. Морозов // Інтелектуальна власність. - 2008. - № 1.

5. Мойсеєнко І. П. Управління інтелектуальним потенціалом: монографія / І. П. Мойсеєнко. - Львів: Аверс, 2007. -303 c.

6. Управління трудовим потенціалом [Електронний ресурс]: навч. посіб. /В.С. Васильченко, А.М. Гриненко, О.А. Грішнова, Л.П. Керб. - К.: КНЕУ, 2005. - 403с.

7. Корчагин Ю. А. Российский человеческий капитал: фрактор развития или деградации?: Монография. - Воронеж: ЦИРЭ, 2005 . - 252 с.

8. Фонарьова Т.А. Удосконалення методичних принципів оцінки вартісних показників людського капіталу»» / Т.А. Фонарьова, В.І. Черняк // Економічний простір»: Збірник наукових праць. - № 52/2. Дніпропетровськ: ПДАБА, 2011.-321c. C.140-150.

9. Політична економія: Навч.-метод. посіб. для самост. вивч. дисципліни / За ред. д-ра екон. наук, проф. К. Т. Кривенка. - К.: КНЕУ, 2003. - 354 с.

10. Мних О. Б. Інтелектуальний капітал і його роль у формуванні вартості машинобудівного підприємства та інноваційній діяльності [Електронний ресурс] / О. Б. Мних // Вісник Національного університету «Львівська політехніка». Логістика. - $2008 . \quad$ № 623 - Режим доступу: http://www.nbuv.gov.ua/portal/natural/Vnulp/Logistyka/2008 623/23.pdf. 


\section{References}

1. Chupryna O.O. Metodolohichni pidkhody do otsiniuvannia intelektualnoho kapitalu / O.O. Chupryna, K.S. Chupryn // Visnyk Natsionalnoho universytetu «lurydychna akademiia Ukrainy imeni Yaroslava Mudroho» № 3 (14) 2013. P. 22-34.

2. Butnik-Siverskyi O.B. Ekonomika intelektualnoi vlasnosti: konspekt lektsii dlia studentiv spetsialnosti 7.000002 «Intelektualna vlasnist». - K.: In-t in tel. vlasn. i prava, 2003. - 296 p.

3. Bazylevych V.D. Intelektualna vlasnist: Pidruchnyk. - Kyiv: Znannia, 2006.-431 p.

4. Morozov O. Systema upravlinnia intelektualnym kapitalom pidpryiemstva yak mekhanizm zakhystu prav intelektualnoi vlasnosti (ch. 1) [Tekst] / O. Morozov // Intelektualna vlasnist. - 2008. - № 1.

5. Moiseienko I. P. Upravlinnia intelektualnym potentsialom: monohrafiia / I. P. Moiseienko. - Lviv: Avers, 2007. - 303 p.

6. Upravlinnia trudovym potentsialom [Elektronnyi resurs]: navch. posib. N.S. Vasylchenko, A.M. Hrynenko, O.A. Hrishnova, L.P. Kerb. - K.: KNEU, 2005. - 403p.

7. Korchagin Yu. A. Rossiyskiy chelovecheskiy kapital: faktor razvitiya ili degradatsii?: Monografiya. - Voronezh: TsIRE, 2005. - $252 \mathrm{p}$.

8. Fonarova T.A. Udoskonalennia metodychnykh pryntsypiv otsinky vartisnykh pokaznykiv liudskoho kapitalu»» / T.A. Fonarova, V.I. Cherniak // Ekonomichnyi prostir»: Zbirnyk naukovykh prats. - № 52/2. Dnipropetrovsk: PDABA, 2011.-321 p. P.140-150.

9. Politychna ekonomiia: Navch.-metod. posib. dlia samost. vyvch. dystsypliny / Za red. d-ra ekon. nauk, prof. K. T. Kryvenka. - K.: KNEU, 2003. - 354 p.

10. Mnykh O. B. Intelektualnyi kapital i yoho rol u formuvanni vartosti mashynobudivnoho pidpryiemstva ta innovatsiinii diialnosti [Elektronnyi resurs] / O. B. Mnykh // Visnyk Natsionalnoho universytetu «Lvivska politekhnika». Lohistyka. - 2008. - № 623 - Rezhym dostupu: http://www.nbuv.gov.ua/portal/natural/Vnulp/Logistyka/2008 623/23.pdf

Стаття поступила 10.01.2019.

Структура:

Вимоги щодо оформлення статей:

УДК

Назва статті українською мовою (регістр як в реченні,

не більш 15 слів без переносів)

Текст статті українською або англійською мовою: Вступ

Автори українською мовою (Прізвище, І.П не більш 6) Назва статті англійською мовою (регістр як в реченні, не більш 15 слів без переносів)

Автори англійською мовою (Прізвище, І.П не більш 6)

Аннотація українська: (200-400 слів), повинна містити:

Мета.

Методика.

Результати.

Наукова новизна.

Практична значущість.

Ключові слова:

Анотація на англійській мові: (200-400 слів) , повинна містити:

Purpose

Methodology

Findings

Originality

Practical value.

Keywords

Аналіз літературних даних та постановка проблеми (обов'язково з аналізом джерел, які індексуються в науково метричних базах даних Scopus або

Webofscience).

Мета і завдання досліджень

Матеріали та методи дослідження

Результати дослідження

Обговорення результатів.

Висновки

Бібліографічний опис згідно ДСТУ 8302:2015 (при наявності у матеріалів індексів DOI або індексування матеріалу в наукометричних базах обов'язково вказувати ці індекси)

References (переклад бібліографрічного опису на англійську мову, або транслітерація його на англійську мову)

Відомості про авторів статті: (на кожного автора: ПІБ, науковий ступінь, місце роботи, ORCID, e-mail, телефон)

Стаття повинна бути оформлена в редакторі Word. Поля 20мм х 20 × 20 × 20. Шрифт Times New Roman, розмір 14, інтервал 1,5 .

Формули повинні бути набрані в об'єкті Microsoft Education 3.0.

Рисунки повинні бути в складі тексту, обтікання виставлено в режим «в тексті», або включені у комірку таблиці з таким же режимом. 